\title{
NITROGEN AND PHOSPHORUS REMOVAL EFFICIENCY OF THREE HELOPHYTES IN CONSTRUCTED SURFACE FLOW WETLANDS FOR URBAN WASTEWATER TREATMENT
}

\author{
Abdeslam EnNabilit ${ }^{1,2^{*}}$ ANd Michel RadouX ${ }^{2 * *}$ \\ ${ }^{I}$ MHEA ${ }^{\circledR}$ International Network, Nobressart, Belgium \\ ${ }^{2}$ Department of Process Engineering, Superior School of Technology, \\ Sidi Mohamed Ben Abdellah University, Fez, Morocco. \\ *Corresponding author: abdeslam.ennabili@usmba.ac.ma \\ **died on June 3, 2017
}

Received: $22^{\text {nd }}$ July 2019; Accepted: $13^{\text {th }}$ March 2020; Published on-line: $4^{\text {th }}$ July 2020)

\begin{abstract}
Nutrient absorption is a function, among others, aimed at macrophytes for wastewater treatment. In this work, Typha angustifolia, Phragmites australis, and Sparganium erectum were multi-annually compared in secondary and tertiary treatment of urban wastewater under Mediterranean climate. Phragmites shows higher growth in height and density during the vegetative period of 1.83-2.09 cm. $\mathrm{d}^{-1}$ and 29-49 times the planting density, respectively. Aerial biomass records 52.2-54.3, 38.1-41.0, and $19.4 \mathrm{t}$ dw.ha ${ }^{-1}$ in Phragmites, Typha, and Sparganium in the same order. The underground biomass fluctuates depending on the rooting vigour from $1.45 \mathrm{t}$ dw.ha ${ }^{-1}$ for Sparganium to $44.49 \mathrm{t} \mathrm{dw} \cdot \mathrm{ha}^{-1}$ for Phragmites in tertiary treatment. Nitrogen and phosphorus aerial mineralomasses are more important in Phragmites $\left(787 \mathrm{~kg} \mathrm{~N} . \mathrm{ha}^{-1}\right)$ and Typha $(107 \mathrm{~kg}$ P.ha ${ }^{-1}$ ) in secondary treatment. Phragmites is, by far, the most cumulative of N and P in its underground part. The $\mathrm{N}$ and $\mathrm{P}$ retention by the vegetated mesocosms apparently has overall relationship with $\mathrm{N}_{-} \mathrm{NH}_{4}{ }^{+}$and $\mathrm{P}-\mathrm{PO}_{4}{ }^{3-}$. Compared to mesocosm input, Phragmites assimilates one's maximum of $6.39 \% \mathrm{~N}$ in its aerial tissues and $7.86 \% \mathrm{P}$ in the underground ones, whereas Typha records maxima of $14.8 \% \mathrm{~N}$ and $33.6 \% \mathrm{P}$ in its aerial part with respect to corresponding mesocosm removal.
\end{abstract}

ABSTRAK:Penyerapan nutrien adalah satu fungsi, antara lain, bertujuan untuk makrofit merawat sisa air. Kajian ini menggunakanTypha angustifolia, Phragmites australis dan Sparganium erectumbagi membandingkan pelbagai-jenis rawatan sekunder dan tertiar sisa air bandar pada iklim Mediterranean. Phragmites menunjukkan pertumbuhan tertinggi dalam ketinggian dan ketumpatandalam tempoh vegetatif iaitu 1.83-2.09 cm.d${ }^{1}$ dan 29-49 kaliketumpatan penanaman, masing-masing. Rekod biojisim udara mencatatkan 52.2-54.3, 38.1-41.0, dan 19.4 t dw.ha ${ }^{-1}$ dalam Phragmites, Typha, dan Sparganium pada susunan sama. Biojisim bawah tanah berubah-ubah bergantung kepada kekuatanakar dari $1.45 \mathrm{t}$ dw.ha ${ }^{-1}$ untuk Sparganium hingga 44.49 t dw.ha ${ }^{-1}$ untuk Phragmites dalam rawatan tertiar. Nitrogen dan Fosforus Mineralomassa udara adalah lebih penting untukPhragmites (787 kg N.ha- $\left.{ }^{-1}\right)$ dan Typha $\left(107 \mathrm{~kg} \mathrm{P} . \mathrm{ha}^{-1}\right)$ dalam rawatan sekunder. Phragmites, setakat ini, paling kumulatif bagi N dan P pada bahagian bawah tanah. Pembendungan $\mathrm{N}$ dan $\mathrm{P}$ oleh mesokisme tumbuh-tumbuhan secara nyata berkaitan dengan $\mathrm{N}_{-} \mathrm{NH}_{4}{ }^{+}$dan $\mathrm{P}-\mathrm{PO}_{4}{ }^{3-}$. Berbanding input mesokisme, Phragmites mengasimilasi maksimum pada N 6.39\% tisu udara dan $\mathrm{P} 7.86 \%$ bahagian bawah tanah, manakala Typha mencatatkan maksima $\mathrm{N} \mathrm{14.8 \%} \mathrm{dan} \mathrm{P} \mathrm{33.6 \%} \mathrm{pada} \mathrm{bahagian} \mathrm{udara}$ dengan penyingkiran mesokisme sepadan. 
KEYWORDS:wastewater; constructed wetland; surface flow; nitrogen; phosphorus

\section{INTRODUCTION}

The use of native macrophytes in constructed wetlands for wastewater treatment has often considered the biology of the species, particularly its life cycle, the tolerance of relatively high pollutant loads, a high productivity of valuable biomass, and local criteria such as climate, wastewater quality, and operating facilities of the treatment process [1-3].

Macrophytes obviously contribute directly or indirectly to the wastewater treatment process $[3,4]$, and the direct absorption of nutrients is one of the desired functions in this regard. Harvesting aerial biomass of helophytes at the end of the growing season could enhance their productivity during the following season, and generally further increase the retention of nutrients, including nitrogen and phosphorus $[5,6]$.

The macrophytes most commonly used in the world in constructed surface flow wetlands (CSFW) correspond to species of Typha, Scirpus, Schoenoplectus, Phragmites, Juncus and Eleocharis genera [3], in addition to Canna, Cyperus, Paspalum and Iris for Mediterranean countries [7]. In Mediterranean Morocco, three helophytes were selected and tested in urban wastewater treatment within the framework of the "MHEA® experimental centre of M'Diq (NW of Morocco)" project, financed by the Walloon Region through the Agence de la Francophonie [8-10], Typha angustifolia L., Phragmites australis (Cav.) Trin. ex Steud. and Sparganium erectum L. These three species have been tested around the world to treat municipal, agricultural, industrial, and drainage waters [3].

Based on overall treatment performance, the experiments carried out in this respect focused on the development and optimization of new extensive wastewater treatment technologies, adapted to the regional climatic and socio-economic conditions (MHEA ${ }^{\circledR}$ processes), with three successive stages each composed of an artificial ecosystem or mesocosm [10].

This work specifically exposes for the first time a multi-year comparison of the three helophytes ( $T$. angustifolia, $P$. australis and $S$. erectum) in secondary and tertiary treatments of urban wastewater, based on development descriptors with annual harvesting of biomass, and their direct contribution to the nitrogen and phosphorus removal in CSFW.

\section{MATERIALS AND METHODS}

\subsection{Mesocosms}

By imitating their respective habitats in natural or polluted environments, $T$. angustifolia $(\mathrm{T}), P$. australis $(\mathrm{Pr})$, and $S$. erectum $(\mathrm{S})$, were grown separately, just before the vegetative period (VP), at a density of 10 rhizomatous fragments per $\mathrm{m}^{2}$ in mesocosms by simulating macrophyte bioreactors: $2.2 \mathrm{~m}^{3}$ of wet volume, including $1.8 \mathrm{~m}^{3}$ of substrate and $0.4 \mathrm{~m}^{3}$ of surface water, and an identical non-planted pond was designed for comparison. The substrate used consists of washed river sand with a particle size of about $38 \%$ (diameter $<2 \mathrm{~mm}), 31.6 \%(2-5 \mathrm{~mm}), 30 \%(>5 \mathrm{~mm})$ and $0.4 \%(<80 \mu \mathrm{m})$. The feeding of these mesocosms in pre-treated wastewater is done semi-continuously and in translation (CSFW). The three planted mesocosms are compared beforehand as secondary treatment, then in the presence of a control (non-planted mesocosm); the mesocosms with T or Pr are compared in secondary and tertiary treatments (Table 1). 
The climate prevailing in the experimental site is of Mediterranean type: rainfall of 523 to $683 \mathrm{~mm}$ (1999-2002), average daily temperatures of $14^{\circ} \mathrm{C}$ to $26^{\circ} \mathrm{C}$, maximum of the warmest months of about $35^{\circ} \mathrm{C}$ (July and August), and minimum of the coldest months above $7^{\circ} \mathrm{C}$ (December and January). The strongest winds are recorded during the months of September (W-E), and November-December (S-N), with negative transient effects of salt spray and plant collapse. Water losses due to mesocosm evapotranspiration vary with planting type and treatment stage, from 5.28 to $19.0 \%$ of inlet flow (Table 2).

Table 1: Characteristics of inlets feeding mesocosms per treatment stage. Sources:

[11-12]; unpublished data.

\begin{tabular}{|c|c|c|c|}
\hline \multirow[t]{4}{*}{ Mesocosms group } & \multicolumn{2}{|c|}{ Secondary inlets (I2) } & \multirow{4}{*}{$\begin{array}{c}\text { Tertiary inlet }(\mathbf{I} 3) \\
\text { Unvegetated control }(\mathrm{L} 3) \\
\text { T. angustifolia }(\mathrm{T} 3) \\
\text { P. australis }(\mathrm{Pr} 3)\end{array}$} \\
\hline & T. angustifolia $(\mathrm{T} 2)$ & Unvegetated control (L2) & \\
\hline & P. australis $(\operatorname{Pr} 2)$ & T. angustifolia $(\mathrm{T} 2)$ & \\
\hline & S. erectum $(\mathrm{S} 2)$ & P. australis( $(\mathrm{Pr} 2)$ & \\
\hline $\mathrm{DCO}\left(\mathrm{mg} \mathrm{O} \mathrm{O}_{2 .} \mathrm{I}^{-1}\right)$ & $402.9 \pm 236.2$ & $292.2 \pm 148.9$ & $34.81 \pm 14.63$ \\
\hline $\mathrm{DBO}_{5}\left(\mathrm{mg} \mathrm{O} . \mathrm{l}^{-1}\right)$ & $115.8 \pm 51.94$ & $110.3 \pm 57.95$ & $32.67 \pm 16.54$ \\
\hline TN (mg N. $\left.\mathbf{l}^{-1}\right)$ & $39.48 \pm 9.446$ & $38.65 \pm 9.906$ & $22.60 \pm 8.332$ \\
\hline $\mathrm{TP}\left(\mathrm{mg} \mathrm{P. \textrm {I } ^ { - 1 }}\right)$ & $6.769 \pm 1.908$ & $6.803 \pm 2.553$ & $4.896 \pm 1.525$ \\
\hline $\mathbf{T}\left({ }^{\circ} \mathbf{C}\right)$ & $22.0 \pm 5.57$ & $22.0 \pm 5.65$ & $20.1 \pm 4.43$ \\
\hline pH & $8.24 \pm 0.58$ & $8.07 \pm 0.61$ & $7.48 \pm 0.19$ \\
\hline $\mathrm{O}_{2}\left(\mathrm{mg.l}^{-1}\right)$ & $10.9 \pm 13.2$ & $10.7 \pm 10.3$ & $5.29 \pm 7.42$ \\
\hline Conductivity $\left(\mu \mathrm{S} . \mathrm{cm}^{-1}\right)$ & $1043.8 \pm 92.463$ & $991.49 \pm 105.19$ & $1136.9 \pm 120.23$ \\
\hline
\end{tabular}

On the other hand duckweed coming to settle in unplanted mesocosms, or in those planted after biomass harvesting, were regularly removed. Diptera and Coleoptera spontaneously succeed in the aquatic and aerial mesocosm compartments, with an affinity of Cladocera and Gastropoda for the first, and Hemiptera and Hymenoptera for the second. Furthermore, the Mosquito Fish [Gambusia affinis (Baird and Girard, 1853), Poeciliidae] was introduced throughout the VP into each of the three mesocosms in secondary treatment: T, Pr and into the un-vegetated one.

Table 2: Water balance in mesocosms per treatment stage. Sources: [11-12]; unpublished data.

\begin{tabular}{|c|c|c|c|c|}
\hline & Mesocosm group & $\begin{array}{l}\text { Inlet flow } \\
\quad\left(\text { l.d }^{-1}\right)\end{array}$ & $\begin{array}{c}\text { Evapotrans- } \\
\text { piration }\left(\mathrm{mm}^{\left.-d^{-1}\right)}\right.\end{array}$ & $\begin{array}{c}\text { Retention time } \\
\left(d^{-1}\right)\end{array}$ \\
\hline \multirow{6}{*}{$\begin{array}{l}\text { Secondary } \\
\text { treatment }\end{array}$} & T. angustifolia(T2) & $186.2 \pm 21.87$ & $16.03 \pm 10.91$ & $2.351 \pm 0.296$ \\
\hline & P. australis $(\operatorname{Pr} 2)$ & $170.8 \pm 19.17$ & $25.92 \pm 13.90$ & $2.673 \pm 0.311$ \\
\hline & S. erectum $(\mathrm{S} 2)$ & $210.2 \pm 23.60$ & $23.55 \pm 13.39$ & $2.152 \pm 0.272$ \\
\hline & Unvegetated control (L2) & $243.0 \pm 39.22$ & $12.84 \pm 17.86$ & $1.810 \pm 0.407$ \\
\hline & T. angustifolia $(\mathrm{T} 2)$ & $217.7 \pm 42.16$ & $16.80 \pm 19.79$ & $2.096 \pm 0.592$ \\
\hline & P. australis $(\operatorname{Pr} 2)$ & $224.9 \pm 50.46$ & $16.03 \pm 17.53$ & $2.072 \pm 0.715$ \\
\hline \multirow{3}{*}{$\begin{array}{c}\text { Tertiary } \\
\text { treatment }\end{array}$} & Unvegetated control (L3) & $132.9 \pm 20.72$ & $22.45 \pm 6.19$ & $3.430 \pm 0.565$ \\
\hline & T. angustifolia(T3) & $137.1 \pm 21.37$ & $16.57 \pm 11.36$ & $3.254 \pm 0.642$ \\
\hline & P. australis $(\operatorname{Pr} 3)$ & $144.4 \pm 22.50$ & $27.47 \pm 10.91$ & $3.244 \pm 0.629$ \\
\hline
\end{tabular}

\subsection{Experimental Monitoring}

Water samples are taken on each mesocosm inlet and outlet approximately every two weeks for analyses of nitrogen compounds (total nitrogen, ammonium, nitrates and nitrites) and phosphorus ones (total phosphorus and orthophosphates). In addition, water samples were also collected to quantify phytoplankton, and macrophyte development parameters were measured. 


\subsubsection{Nitrogen}

Total nitrogen (TN) and total non-particulate nitrogen (TNf) are determined after digestion of the sample in an alkaline medium $(\mathrm{NaOH})$ in the presence of persulfate whereby the nitrogen compounds convert to nitrates. Undigested persulfate is reduced by sodium metabisulfite. Nitrates react with chromotropic acid in a strong acid medium $\left(\mathrm{H}_{2} \mathrm{SO}_{4}\right)$ to form a yellow complex with maximum absorbance at $410 \mathrm{~nm}$. Two ranges are proposed by the Hach firm: the low range $\left(0.2-25 \mathrm{mg} \mathrm{N} . \mathrm{l}^{-1}\right)$ and the high range $(7-150 \mathrm{mg}$ N. $\left.1^{-1}\right)$.

Ammonium ions $\left(\mathrm{NH}_{4}^{+}\right)$are determined according to the Nessler method on filtered samples. The hardness of the sample is complexed by a mineral stabilizer. The polyvinyl alcohol, a dispersing agent, helps to form a yellow colour with the Nessler reagent in the presence of the ammonium ions. The colouring developed is proportional to the concentration of ammonia. The reading is at $425 \mathrm{~nm}$ for a concentration range 0.05 to 2.5 $\operatorname{mg~N} .1^{-1}$.

Nitrite ions $\left(\mathrm{NO}_{2}{ }^{-}\right)$are determined according to the sulfanilamide method whose principle is the formation of a diazonium compound by the reaction of nitrites with sulfanilamide. This compound gives, by coupling with $\mathrm{N}$-(1-naphthyl)-ethylenediamine dichloride, a red-mauve colour measured at $540 \mathrm{~nm}$. The range used is 0.003 to $0.3 \mathrm{mg}$ $\mathrm{N} .1^{-1}$. Nitrate ions $\left(\mathrm{NO}_{3}{ }^{-}\right)$are reduced by cadmium to nitrite ones which react in acidic medium with sulfanilic acid to form an intermediate diazonium salt. The latter reacts with gentisic acid and forms an amber colour determined at $500 \mathrm{~nm}$ for the high range $(0-30 \mathrm{mg}$ $\left.\mathrm{N} .1^{-1}\right)$ and at $400 \mathrm{~nm}$ for the medium range $\left(0-5 \mathrm{mg} \mathrm{N} . \mathrm{l}^{-1}\right)$. For the low range (0-0.5 $\mathrm{mg} \mathrm{N} . \mathrm{l}^{-}$ ${ }^{1}$ ), the diazonium reagent reacts with chromotropic acid and develops a yellow colour measured at $507 \mathrm{~nm}$.

\subsubsection{Phosphorus}

Total phosphorus (TP) and total non-particulate phosphorus (TPf) are oxidized as orthophosphate ions in acidic medium in the presence of persulfate. Two ranges are used: (i) the low range $\left(0-3.5 \mathrm{mg} \mathrm{P.1^{-1 } )}\right.$ for which orthophosphate reacts with molybdate in an acid medium to produce a phosphomolybdic complex which, in turn, is reduced by ascorbic acid giving an intense molybdenum blue coloration determined at $890 \mathrm{~nm}$; (ii) the high range (0-100 mg P.1 $\left.{ }^{-1}\right)$ for which the phosphomolybdic complex forms in the presence of vanadium the yellow vanadomolybdophosphoric complex measured at $420 \mathrm{~nm}$.

Orthophosphate ions $\left(\mathrm{PO}_{4}{ }^{3-}\right)$ react, in acid medium, with the ammonium molybdate producing the molybdophosphoric acid. This complex is then reduced by the amino acid reagent to form the blue-molybdenum intensely coloured to determine at $530 \mathrm{~nm}$. The

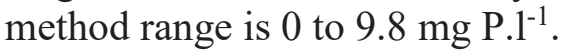

\subsubsection{Phytoplankton}

According to the algae density in mesocosms, an adequate volume is taken at a depth of $10 \mathrm{~cm}$. The phytoplankton biomass was evaluated by the chlorophyll-a determination in accordance with the spectrophotometric method specified in Standard Methods [13].

\subsubsection{Helophytes}

Macrophyte development parameters include stem density and height, biomass production, and $\mathrm{N}$ and $\mathrm{P}$ contents in their tissues. At the end of the VP the aerial part of each helophyte is cut above the water level, and its dead parts are collected separately to estimate respectively the above-ground biomass, and the necromass inside the mesocosm. 
In addition during each VP, cuttings of the plant aerial part beyond mesocosms were sometimes required because of accessibility.

At the end of the $3^{\text {rd }}$ VP, the mesocosms are emptied, and the rhizomes and roots of the middle $3^{\text {rd }}$ are gently recovered and washed on stacked sieves with a regressive mesh for the estimation of the underground biomass. Representative subsampling of collected biomass is adopted, and the following analytical steps (drying, grinding, and $\mathrm{N}$ and $\mathrm{P}$ determination) were conducted according to Ennabili et al. [14].

\subsection{Analytical Methods}

Data are presented depending on three periods: vegetative period (VP), vegetative rest (VR) and "VP+VR". The one-way analysis of variance (ANOVA) of normal distribution data was performed using the STATISTICA software, V.5, otherwise only averages and standard deviations were calculated using Microsoft Excel software.

\section{RESULTS AND DISCUSSION}

\subsection{Helophyte Development}

\subsubsection{Growth}

$\operatorname{Pr}$ develops more in height especially in tertiary treatment $(\operatorname{Pr} 3)$, successively followed by $\mathrm{T}$ and $\mathrm{S}$ (Table 3 ). These values greatly exceed those previously reported in $\mathrm{T}$, $\mathrm{Pr}$, and S grown in constructed wetlands, under polluted environments, or those developed in greenhouses, specifically $1.79-2.50 \mathrm{~m}$ for $\mathrm{Pr}, 0.90-1.99 \mathrm{~m}$ for $\mathrm{T}$ and $0.91 \mathrm{~m}$ for $\mathrm{S}$ [15$18]$, and are close to those underlined in natural or polluted environments, $3.2-3.5 \mathrm{~m}$ for Pr, $2.8 \mathrm{~m}$ for $\mathrm{T}$ and $1.70 \mathrm{~m}$ for $\mathrm{S}[6,14]$.

Table 3: Growth characteristics and above (A-) and underground (U-) biomass of helophytes studied per treatment level.

\begin{tabular}{|c|c|c|c|c|c|}
\hline Mesocosms & $\mathbf{T 2}$ & T3 & Pr2 & Pr3 & S2 \\
\hline Height (m) & $3.47 \pm 0.59$ & $3.15 \pm 0.49$ & $3.90 \pm 0.87$ & $4.45 \pm 0.71$ & $1.96 \pm 0.98$ \\
\hline Stems.m. ${ }^{-2}$ & $86 \pm 52$ & $38 \pm 24$ & $494 \pm 217$ & $289 \pm 140$ & $79 \pm 31$ \\
\hline \multirow[t]{2}{*}{ Fertile stems (\%) } & 17.58 & 43.59 & 20.43 & 17.49 & 34.78 \\
\hline & \pm 14.00 & \pm 67.48 & \pm 10.61 & \pm 8.044 & \pm 26.65 \\
\hline \multirow[t]{2}{*}{ A-dry weight ( $\%$ wet weight) } & 19.47 & 19.60 & 39.33 & 43.13 & 15.17 \\
\hline & \pm 4.969 & \pm 4.623 & \pm 1.343 & \pm 3.721 & \pm 6.536 \\
\hline \multirow[t]{2}{*}{ A-Biomass (t dw.ha' $\left.{ }^{-1}\right)$} & 41.009 & 38.098 & 54.284 & 52.209 & 19.436 \\
\hline & \pm 13.785 & \pm 15.286 & \pm 30.850 & \pm 36.400 & \pm 12.125 \\
\hline \multirow[t]{2}{*}{ A-Necromass (t dw.ha $\left.{ }^{-1}\right)$} & 5.850 & 6.220 & 7.310 & 2.745 & 9.075 \\
\hline & \pm 5.459 & \pm 7.269 & \pm 9.914 & \pm 3.627 & \pm 10.60 \\
\hline \multirow[t]{2}{*}{ A-partial pre-cutting ( $\left(\mathrm{dw} \cdot \mathrm{ha}^{-1}\right)$} & 0.951 & 0.927 & 4.021 & 3.413 & 0.538 \\
\hline & \pm 0.369 & \pm 0.773 & \pm 2.396 & \pm 3.787 & \pm 0.371 \\
\hline \multirow[t]{2}{*}{ Net productivity $\left(\mathrm{t}\right.$ dw.ha $\left.\mathbf{a}^{-1} \cdot \mathrm{y}^{-1}\right)$} & 59.895 & 52.428 & 70.113 & 50.098 & 22.272 \\
\hline & \pm 4.2172 & \pm 20.601 & \pm 65.025 & \pm 54.739 & \pm 6.6706 \\
\hline U-Biomass (\% ww) & 6.80 & 18.47 & 22.20 & 22.27 & 6.78 \\
\hline U-Biomass (t dw.ha- $\left.{ }^{-1}\right)$ & 4.363 & 7.998 & 25.008 & 44.486 & 1.454 \\
\hline "U/A-Biomass" ratio & 0.22 & 0.34 & 0.38 & 0.65 & 0.04 \\
\hline
\end{tabular}

The average growth rate during the VP is $1.83-2.09,1.48-1.63$ and $0.92 \mathrm{~cm} . \mathrm{d}^{-1}$ for $\mathrm{P}$, $\mathrm{T}$, and $\mathrm{S}$ in the same order, vs. 0.77-1.9 $\mathrm{cm} \cdot \mathrm{d}^{-1}$ underlined in Pr by Zheng et al. [6] and Zhang et al. [17]. The shoot collapse is spectacular in S especially during the "AugustOctober" period as it was noted in a polluted environment by Ennabili and Gharnit [19], due to the cumulated effect of sludge discharge and wind. Asaeda et al. [20] point out that 
collapsed shoots disappear in 40-60 days and constitute a large fraction of the floating organic matter.

Horizontal stems of Pr sometimes robustly branch out from rhizomes during fruiting (July), reaching $9 \mathrm{~m}$ in length with an average of 3 sprouts. $\mathrm{m}^{-1}$ (September), and becoming rhizome once into the inlet piped water of mesocosms. Aquatic stolons are also observed in $\mathrm{T}$ during the flowering-fruiting period.

Typically more apparent at the mesocosm margins, stem density at the end of VP increased by about 29-49, 3.8-8.6, an 7.9 times for $\mathrm{Pr}, \mathrm{T}$, and $\mathrm{S}$, respectively, compared to the initial planting, exceeding for Pr the range of $130-175$ plants. $\mathrm{m}^{-2}$ (17-18 times the planting density) highlighted by Zheng et al. [6], and the 107 plants. $\mathrm{m}^{-2}$ cited in a polluted environment [15]. The increased rates of "post-planting density" obtained by this author in greenhouse approach noted in this work, 53.0 and 8.47 times the planting density of Pr and $\mathrm{S}$ respectively, but substantially different from that of $\mathrm{T}$ (21.9 times). Those high values of densities are related, inter alia, to the high tillering rate in these species, particularly 15, 6 and 3 sprouts.plant ${ }^{-1}$, respectively for $\operatorname{Pr}, \mathrm{T}$, and S [15], and to the annual cut of helophyte aerial parts [6].

Although peak flowering occurs in September, secondary flowering cohorts are noted along the VP: T (April, June-August), Pr (April, August), and S (April-May, July-August, October). The flowering rate is likely to vary inversely with the treatment stage, contrary to $\operatorname{Pr}$ (Table 3), and it is negatively affected in $\mathrm{S}$ by the shoot collapse just before flowering. However, this species completes more than one development cycle per VP, with a maximum of 3 during the $3^{\text {rd }}$ year of mesocosm functioning. In addition, $\mathrm{S}$ seeds massively germinate from the mesocosm bottom or on water surface (Fig. 1). In addition, the sucking of $\mathrm{S}$ is also more remarkable in the canopy openings created by the shoot collapse in mid-summer.

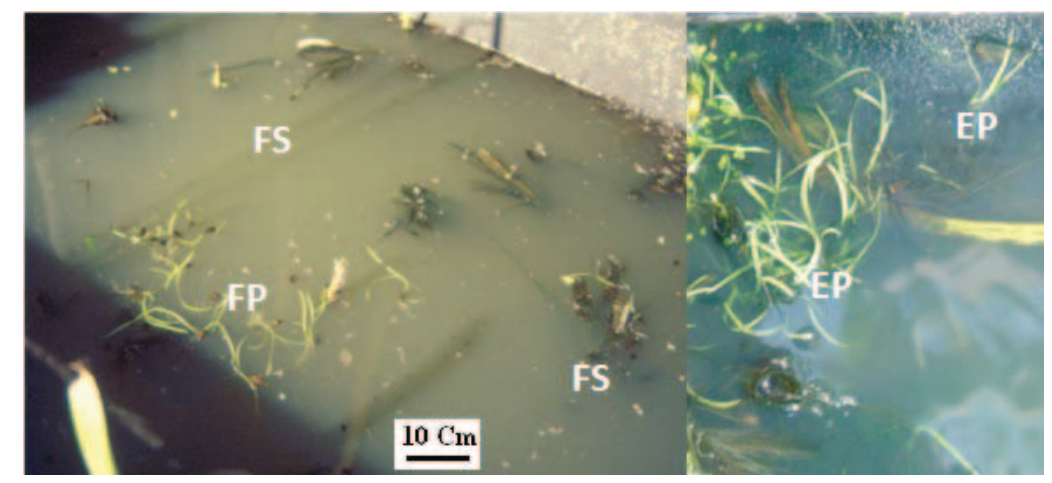

Fig. 1: Seed germination and development of $S$. erectum. FP, floating plantlets; FS, floating seeds; EP, emergent plantlets.

Moreover, the root bed is thicker in $\mathrm{Pr}$, followed successively by $\mathrm{T}$ and $\mathrm{S}$, and overwhelmingly achieves about 107, 56.7 and $20.6 \mathrm{~cm}$ deep from the level of substrate in the mesocosm middle part, respectively (Fig. 2). Liffen et al. [21] found that the biomass of $\mathrm{S}$ roots and rhizomes was highest at a depth of $0-10 \mathrm{~cm}$, with a gradual decrease to 20$25 \mathrm{~cm}$.

Rhizomes and roots of Pr go through the whole mesocosm substrate, forming root plaques at the bottom, and oxygenating the full height of the mesocosm bed except a slightly anoxic intermediate layer in appearance. The oxygen release from the Pr roots in the rhizosphere is qualitatively marked by a reddish colour, associated with the oxidized 
forms of iron [4]. Pr rhizomes sometimes damage the mesocosm outlet by penetrating duct junctions.

\subsubsection{Biomass}

The above-ground biomass of helophytes is found to be slightly disadvantaged in tertiary treatment, with lower hydraulic loads (Table 2) and nutrients (Table 1), and ranges from $19.44 \mathrm{t} \mathrm{dw} \cdot \mathrm{ha}^{-1}$ for S2 to 52.21-54.28 t dw.ha ${ }^{-1}$ for Pr2, according to the lignification gradient, especially dry weights ( $\mathrm{dw}$ ) of 15.2 to $39.3-43.1 \%$ of the wet weight (ww) in the same order (Table 3). Which corresponds to a production in VP of about $0.193,0.179$, 0.255, 0.245 and $0.091 \mathrm{t} \mathrm{dw} \cdot \mathrm{ha}^{-1} \cdot \mathrm{d}^{-1}$ for T2, T3, Pr2, Pr3 and S2, vs. 0.14, 0.16 and 0.10 reported by Ennabili [15] in glasshouse, respectively for T, Pr and S.

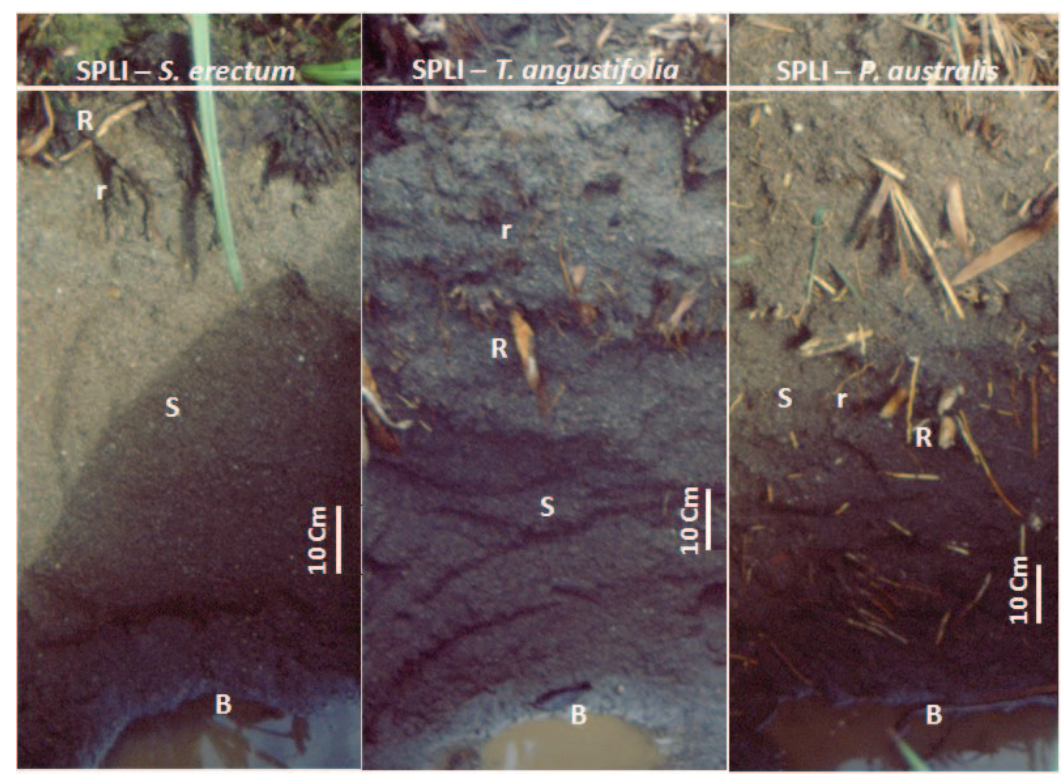

Fig. 2: Side view of dewatered mesocosm substrate after three vegetation periods. B, mesocosm bottom; R, rhizome; r, root; S, sand; SPLI, "sand/plant litter" interface.

Disregarding the role of study conditions, the aboveground biomass values obtained exceed those underlined in $\operatorname{Pr}\left(5.40-37.2 \mathrm{t}\right.$ dw.ha ${ }^{-1}$, vs. 52.2-54.3 t dw.ha-1) [6,14-16,18, 22-25], were similar to those reported for $\mathrm{T}$ (7.76-33.0 t dw.ha- ${ }^{-1}$, vs. 38.1-41.0 t dw.ha ${ }^{-1}$ ) [14-15,18,26], and were part of the range of values highlighted in S [14-15,20-21].

The above-ground biomass during three successive years with harvesting of helophyte aerial parts at the end of each VP shows that Pr has a relative stability of production in tertiary treatment, a resilience for Pr and S in secondary treatment, while the T biomass increases in the first two years and falls steeply in the third year compared to the 3-year average (Fig. 3). The positive impact of harvesting on biomass production has been demonstrated in $\operatorname{Pr}[6,25]$. Due to non-harvesting of biomass de los Reyes et al. [26] showed that the $\mathrm{T}$ biomass improved by about 39 to $48 \%$ in the $3^{\text {rd }}$ year for the aboveground and below-ground parts respectively, suggesting an inadequacy of medium and long-term harvest for these species growing in CSFW.

The partial cut of helophytes for accessibility along the VP exports from $0.075 \mathrm{t} \mathrm{dw} \cdot \mathrm{ha}^{-1}$ for S2 to $4.021 \mathrm{tdw} \cdot \mathrm{ha}^{-1}$ for Pr2. The specific necromass collected after harvesting is higher for $\mathrm{S}\left(9.075 \mathrm{t} \mathrm{dw} \cdot \mathrm{ha}^{-1}\right)$, due especially to the shoot collapse, followed in descending order by those of Pr2, T3, T2 and Pr3 (Table 3), which would probably be a source of mesocosm enrichment during the forthcoming seasons. The net aboveground 
productivity varies from more than $22 \mathrm{t} \mathrm{dw} \cdot \mathrm{ha}^{-1}$.year ${ }^{-1}$ for $\mathrm{S}$ to over $70 \mathrm{tdw} \cdot \mathrm{ha}^{-1} \cdot \mathrm{y}^{-1}$ for $\operatorname{Pr}$ in secondary treatment (Table 3), exceeding the estimated total biomass by Maucieri et al. [27] in $\operatorname{Pr}\left(49.2-58.9 \pm 9.1 \mathrm{t} \mathrm{dw} \cdot \mathrm{ha}^{-1}\right)$ in CSFW for agricultural wastewater treatment.

As far as the underground biomass, it fluctuates from $1.454 \mathrm{t}$ dw.ha ${ }^{-1}$ for $\mathrm{S}$ to $44.486 \mathrm{t}$ $\mathrm{dw} \cdot \mathrm{ha}^{-1}$ for $\operatorname{Pr}$ in tertiary treatment, approximately 4 to $65 \%$ of the respective aboveground biomasses (Table 3). These values overlap with those underlined for $\operatorname{Pr}\left(16.0-29.7 \mathrm{t} \mathrm{dw} \cdot \mathrm{ha}^{-}\right.$ , , vs. 25.0-44.5 t dw.ha ${ }^{-1}$ ) [14-15,23], but are outperformed by those reported for $\mathrm{T}$ (12.334.95 t dw.ha- ${ }^{-1}$, vs. 4.36-8.00 t dw.ha $\left.{ }^{-1}\right)$ and $S\left(6.49 .48-23.5 \mathrm{t} \mathrm{dw} \cdot \mathrm{ha}^{-1}\right.$, vs. $\left.19.4 \mathrm{t} \mathrm{dw} . h \mathrm{~h}-1\right)$ $[14-15,21,26]$.

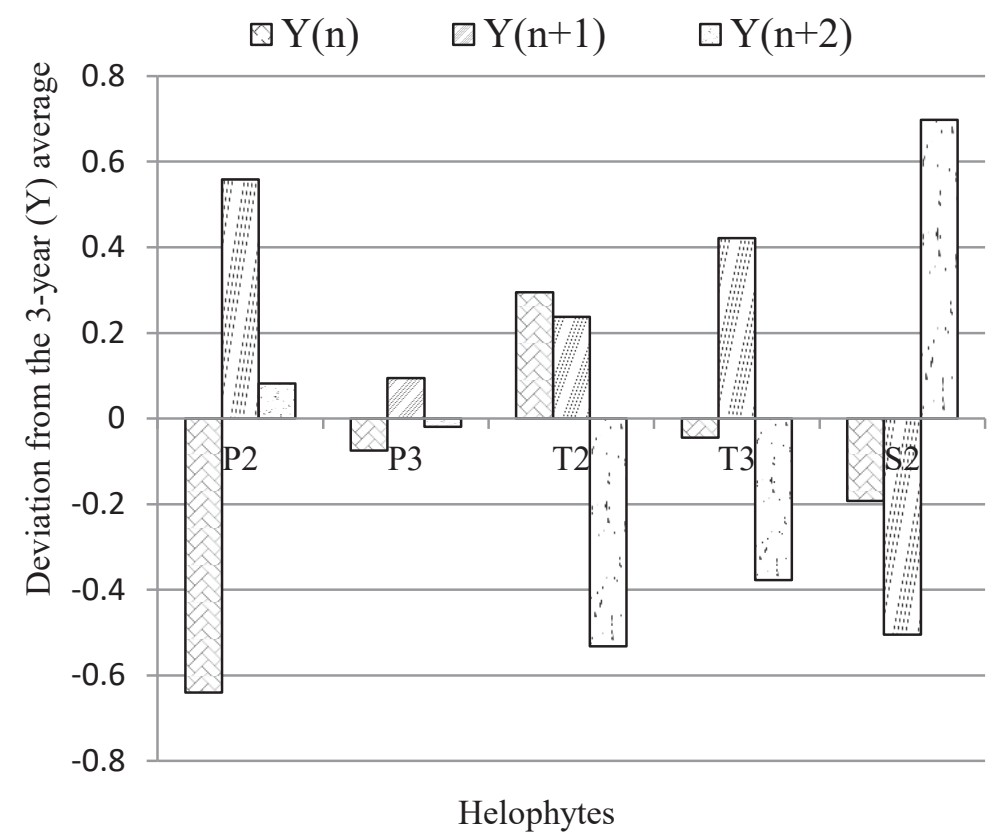

Fig. 3: Annual aboveground biomass in relation to the 3-year average one.

The above-ground biomass apparently is more favoured in CSFW (U/A of 0.04 to 0.65 depending on the species and the treatment stage) in comparison with the underground biomass (Table 3), contrary to the ratios obtained in polluted environments: $1.62,1.62$ and 0.55 for $\mathrm{T}, \operatorname{Pr}$ and $\mathrm{S}$ in the same order [14]. However, by referring to the biomass averages obtained in these species from the same source by the same authors, and considering the harvest conditions at the end of each VP, CSFW systematically favour the aboveground biomass production (Fig. 4). The underground biomass is also favoured but with a lower intensity in Pr and T in tertiary treatment.

\subsubsection{Mineralomass}

The N/P contents in aerial tissues of helophytes are more apparent in $\operatorname{Pr}$ and $\mathrm{T}$ in secondary treatment, specially $787 \mathrm{~kg} \mathrm{~N} . \mathrm{ha}^{-1} / 89.6 \mathrm{~kg} \mathrm{P} . \mathrm{ha}^{-1}$, and $670 \mathrm{~kg} \mathrm{~N} \cdot \mathrm{ha}^{-1} / 107 \mathrm{~kg}$ P.ha ${ }^{-1}$ in the same order. The lowest rates for these two nutrients were recorded in $\mathrm{T}$ in tertiary treatment (Table 4). As regards the underground mineralomass $\operatorname{Pr}$ is the most cumulative of $\mathrm{N}$ and $\mathrm{P}$, apparently due to its high underground biomass in CSFW. 


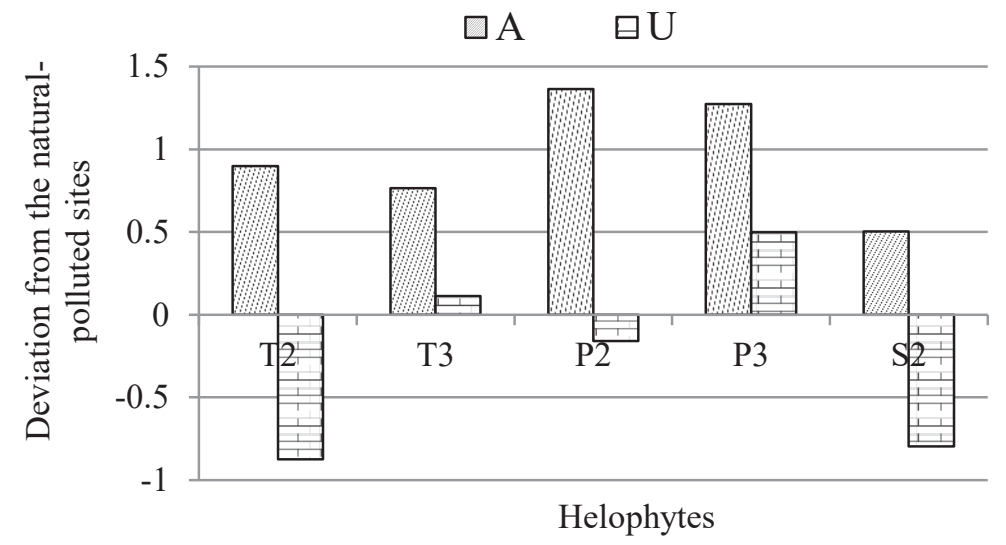

Fig. 4: Helophyte above-(A) and underground (U) biomass in relation to naturalpolluted sites [14] and CSFW (the present study).

Table 4: Nitrogen and phosphorus contents and mineralomass in above (A-) and underground (U-) parts of helophytes studied per treatment level.

\begin{tabular}{|c|c|c|c|c|c|}
\hline Mesocosms & $\mathbf{T} 2$ & T3 & Pr2 & Pr3 & S2 \\
\hline A-N (\%) & $1.64 \pm 0.83$ & $0.92 \pm 0.25$ & $1.45 \pm 0.85$ & $1.26 \pm 0.47$ & $1.90 \pm 0.29$ \\
\hline A-P (\%) & $0.26 \pm 0.10$ & $0.16 \pm 0.08$ & $0.17 \pm 0.05$ & $0.13 \pm 0.01$ & $0.45 \pm 0.13$ \\
\hline U-N (\%) & 1.23 & 0.62 & 1.00 & 1.08 & 1.08 \\
\hline U-P (\%) & 0.21 & 0.14 & 0.19 & 0.23 & 0.19 \\
\hline A-N (kg N.hat $\left.{ }^{-1}\right)$ & $670.49 \pm 225.38$ & $348.60 \pm 139.87$ & $787.12 \pm 447.33$ & $657.84 \pm 458.64$ & $368.31 \pm 229.76$ \\
\hline A-P (kg P.hat $\left.{ }^{-1}\right)$ & $106.62 \pm 35.840$ & $59.052 \pm 23.693$ & $89.569 \pm 50.903$ & $67.872 \pm 47.320$ & $86.490 \pm 53.955$ \\
\hline U-N (kg N.ha $\left.{ }^{-1}\right)$ & 53.669 & 49.589 & 250.08 & 480.45 & 15.703 \\
\hline U-P (kg P.ha $\left.{ }^{-1}\right)$ & 9.1629 & 11.197 & 47.515 & 102.32 & 2.7625 \\
\hline
\end{tabular}

Compared to the $\mathrm{dw}$, the N/P contents in helophyte tissues intersect those reported by other authors in $\mathrm{Pr}$, except the low values of $\mathrm{N}$ in the underground part (Table 4), respectively $1.10-3.11 / 0.09-0.27 \% \mathrm{dw}$ of the aerial part, and $1.44-1.73 / 0.22-0.32 \% \mathrm{dw}$ of the underground one $[2,5-6,14,18]$. For $\mathrm{T}$ and $\mathrm{S}$ the values underlined by other works are $1.94 / 0.09-0.17 \%$ and $1.94 / 0.35 \% \mathrm{dw}$ of the aerial tissues, and $1.04 / 0.15 \%$ and $1.73 / 0.55 \%$ of the aerial tissues in the same order $[14,18]$.

The mineralomass values reported by other studies clearly distinguish the N/P aboveground mineralomasses of $\operatorname{Pr}\left(658-787 \mathrm{~kg} \mathrm{~N} \cdot \mathrm{ha}^{-1} / 68-90 \mathrm{~kg}\right.$ P.ha $\left.{ }^{-1}\right)$, vs. 111-502 kgN.ha ${ }^{-1} / 17-37.4$ Kg P.ha ${ }^{-1}[6,14,16,24,25,27-29]$, and show an harmony of its N/P underground mineralomasses $\left(250-480 \mathrm{~kg} \mathrm{~N}^{-h^{-1} / 48-102} \mathrm{~kg} \mathrm{P}^{-h^{-1}}\right)$ vs. $503.3 \mathrm{kgN} \cdot \mathrm{ha}^{-}$ 1/32.02-76.9 kg P.ha' ${ }^{-1}[6,14]$.

When compared with other authors, the N/P aboveground mineralomasses of $\mathrm{T}$ and $\mathrm{S}$ are similar (Table 4), vs. 74-420 kgN.ha- $/ 20-55 \mathrm{~kg} \mathrm{P} \cdot \mathrm{ha}^{-1}$ for $\mathrm{T}$ and $251-300 \mathrm{kgN} \cdot \mathrm{ha}^{-}$ 1/45.3-50 kg P.ha ${ }^{-1}$ for S $[14,26,28,29-31]$, while the N/P belowground ones are largely disadvantaged in this respect (Table 4), vs. 310-822 kgN.ha-1/5-147 kg P.ha-1 for T and 124.3 kgN.ha-1/39.5 kg P.ha-1 for S [14,26].

\subsection{Phytoplanktonic Chlorophyll-a}

The chlorophyll-a content in mesocosm water varies widely throughout the growing cycle. In secondary treatment and as compared to $\mathrm{T}$ and $\mathrm{S}$ (Fig. 5), the Pr-mesocosm generally reduces more phytoplankton $\left(0.0171 \pm 0.0200 \mathrm{mg}\right.$ Chlorophyll-a. $\left.\mathrm{l}^{-1}\right)$ and especially during the VR $\left(0.0066 \pm 0.0069 \mathrm{mg}^{-1} \mathrm{l}^{-1}\right)$; this fact is more apparent in the T- 
mesocosm in the VP $\left(0.0174 \pm 0.0196 \mathrm{mg}^{-1} \mathrm{l}^{-1}\right)$. In tertiary treatment, the Pr-mesocosm forcefully reduces phytoplankton $\left(0.0038 \pm 0.0105 \mathrm{mg} .1^{-1}\right)$, compared to a lesser role of Tmesocosm, and an algae enrichment of the un-vegetated one (Fig. 5). This particular behaviour of the Pr-mesocosm is apparently in relation with, among other things, its leaf canopy more developed throughout the year.

In addition to the indirect role of helophyte shading on phytoplankton contraction, authors have shown allelopathic interferences of macrophytes with phytoplankton development. For example, extracts of leaves, stems and rhizomes of Pr can have negative effects on the growth of freshwater phytoplankton, Microcystis and Scenedesmus [32]. T and its allelochemicals can control phytoplankton blooms in eutrophic waters [33]. Cyanobacteria can also produce effective allelochemicals that interfere with the growth of competitive Cyanobacteria and algae [34].

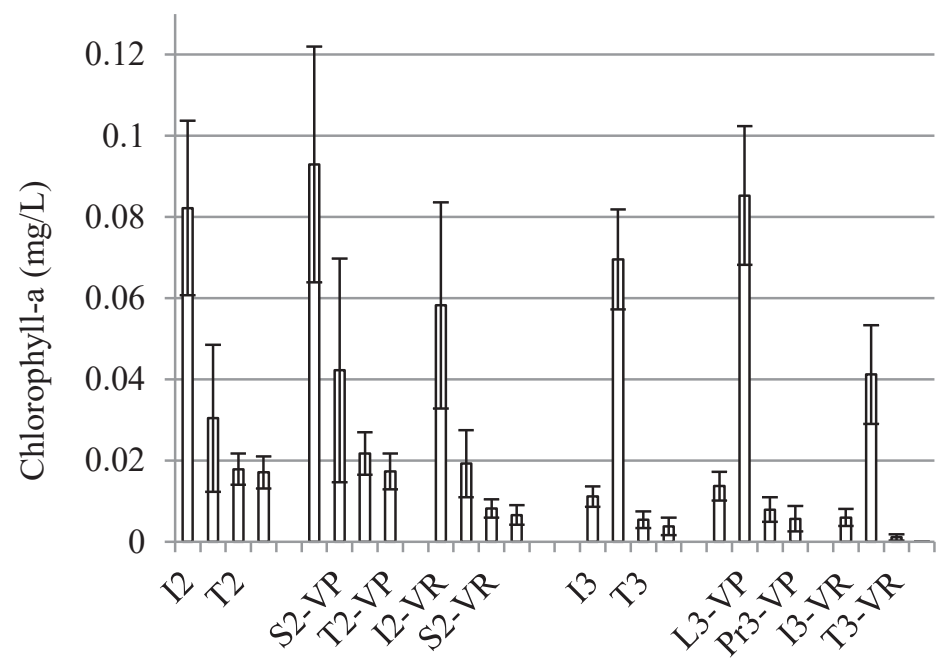

Inlets and outlets of mesocosms

Fig. 5: Chlorophyll-a content of mesocosm inlet (I) and outlets (June 99-Sep.00).

\subsection{Nitrogen and Phosphorus Removal Efficiency}

In secondary treatment, the Pr-mesocosm has an advantage for the retention of $\mathrm{TN}$, TNf and $\mathrm{NH}_{4}^{+}$in comparison with the T and $\mathrm{S}$ ones (Table 5), but it's similar to Tmesocosm and the non-planted one (L) for TN and TNf (Table 6). In tertiary treatment, it generates the best TN removal, and aggregates with $\mathrm{L}$ for TNf and $\mathrm{NH}_{4}^{+}$, and with $\mathrm{L}$ and I (mesocosm inlet) for $\mathrm{PO}_{4}{ }^{3-}$ (Table 7). S- and T-mesocosms would be of interest for the retention of $\mathrm{NO}_{3}{ }^{-}$and $\mathrm{NO}_{2}{ }^{-}$in secondary and tertiary treatments in the same order (Table 5 and 7).

The L-mesocosm shows significant removal of $\mathrm{NH}_{4}^{+}$and $\mathrm{TPf}$ respectively in secondary and tertiary treatments, and generates similar concentrations of $\mathrm{NO}_{3}{ }^{-}$and $\mathrm{PO}_{4}{ }^{3-}$ to those of I in secondary treatment (Tables 6 and 7). Depending on the I-water quality, planting of mesocosms apparently has no effect on the retention of $\mathrm{NO}_{3}{ }^{-}$and $\mathrm{PO}_{4}{ }^{3-}$ in secondary treatment, and of $\mathrm{PO}_{4}{ }^{3}$-in tertiary treatment (Tables 5, 6 and 7). The impact of the $\mathrm{VP}$ on the $\mathrm{N}$ and $\mathrm{P}$ retention likely has a general relationship with the direct plant uptake of N-NH${ }_{4}^{+}$and $\mathrm{PO}_{4}{ }^{3-}$, but remains without clear trend for TNf, $\mathrm{NO}_{2}{ }^{-}, \mathrm{NO}_{3}{ }^{-}$and TPf (Tables 5, 6 and 7), seemingly due to other factors such as bacterial activity, substrate composition, hydraulic retention time, etc. 
Table 5: Nitrogen and phosphorus contents $\left(\mathrm{mg} . \mathrm{l}^{-1}\right)$ of inlet and outlets of T-, Pr-, and S-mesocosms (Secondary treatment; Jan. 99 - Sep. 00).

\begin{tabular}{|c|c|c|c|c|c|c|c|}
\hline & \multirow{2}{*}{$\begin{array}{c}\text { Inlet } \\
\mathrm{I} 2\end{array}$} & \multicolumn{3}{|c|}{ Outlets } & \multicolumn{3}{|c|}{ ANOVA significance $(p<0.05)$} \\
\hline & & $\mathrm{T} 2$ & $\operatorname{Pr} 2$ & S2 & F-ratio & F-prob. & Effet \\
\hline TN & $39.5 \pm 9.45 \mathrm{a}$ & $31.6 \pm 8.33 \mathrm{~b}$ & $22.8 \pm 10.36 \mathrm{c}$ & $31.2 \pm 8.96 \mathrm{~b}$ & 21.37 & 0.0000 & $* * *$ \\
\hline VP & $38.3 \pm 9.39 \mathrm{a}$ & $31.6 \pm 8.07 \mathrm{~b}$ & $22.9 \pm 10.74 \mathrm{c}$ & $30.1 \pm 8.56 \mathrm{~b}$ & 13.62 & 0.0000 & $* * *$ \\
\hline VR & $42.5 \pm 9.35$ & $31.5 \pm 9.37$ & $22.6 \pm 9.77$ & $34.0 \pm 9.79$ & - & - & - \\
\hline TNf & $26.6 \pm 8.09 \mathrm{a}$ & $25.7 \pm 6.91 \mathrm{a}$ & $19.0 \pm 7.67 \mathrm{~b}$ & $25.5 \pm 10.36 \mathrm{a}$ & 6.597 & 0.0003 & $* * *$ \\
\hline VP & $26.0 \pm 8.83 \mathrm{a}$ & $26.3 \pm 7.16 \mathrm{a}$ & $19.5 \pm 7.85 \mathrm{~b}$ & $25.7 \pm 10.54 \mathrm{a}$ & 3.852 & 0.0117 & $*$ \\
\hline VR & $28.1 \pm 6.02$ & $24.1 \pm 6.28$ & $17.9 \pm 7.48$ & $24.8 \pm 10.4$ & - & - & - \\
\hline $\mathrm{NH}_{4}{ }^{+}$ & $21.6 \pm 5.89 \mathrm{a}$ & $21.0 \pm 8.06 \mathrm{a}$ & $13.3 \pm 6.20 \mathrm{~b}$ & $20.5 \pm 7.59 \mathrm{a}$ & 12.89 & 0.0000 & *** \\
\hline VP & $21.4 \pm 5.67 \mathrm{a}$ & $22.4 \pm 6.37 \mathrm{a}$ & $14.1 \pm 5.70 \mathrm{~b}$ & $21.1 \pm 6.12 \mathrm{a}$ & 12.55 & 0.0000 & $* * *$ \\
\hline VR & $22.0 \pm 6.74$ & $17.3 \pm 11.1$ & $11.2 \pm 7.26$ & $18.7 \pm 10.9$ & - & - & - \\
\hline $\mathrm{NO}_{2}^{-}$ & $0.016 \pm 0.021$ & $0.014 \pm 0.020$ & $0.019 \pm 0.018$ & $0.008 \pm 0.008$ & - & - & - \\
\hline VP & $0.022 \pm 0.024$ & $0.017 \pm 0.024$ & $0.014 \pm 0.012$ & $0.008 \pm 0.009$ & - & - & - \\
\hline VR & $0.005 \pm 0.005$ & $0.008 \pm 0.007$ & $0.030 \pm 0.023$ & $0.007 \pm 0.006$ & - & - & - \\
\hline $\mathrm{NO}_{3}^{-}$ & $0.252 \pm 0.236 \mathrm{a}$ & $0.340 \pm 0.317 \mathrm{a}$ & $0.217 \pm 0.214 \mathrm{a}$ & $1.056 \pm 1.894 \mathrm{~b}$ & 3.318 & 0.0243 & * \\
\hline $\mathbf{V P}$ & $0.235 \pm 0.192$ & $0.278 \pm 0.273$ & $0.149 \pm 0.090$ & $0.141 \pm 0.102$ & - & - & - \\
\hline VR & $0.278 \pm 0.303$ & $0.432 \pm 0.372$ & $0.320 \pm 0.301$ & $2.428 \pm 2.477$ & - & - & - \\
\hline TP & $6.77 \pm 1.91 \mathrm{a}$ & $7.05 \pm 1.54 \mathrm{a}$ & $6.53 \pm 1.81 \mathrm{a}$ & $7.00 \pm 1.61 \mathrm{a}$ & 0.782 & 0.5058 & NS \\
\hline VP & $7.00 \pm 1.72 \mathrm{a}$ & $7.31 \pm 1.30 \mathrm{a}$ & $7.02 \pm 1.73 \mathrm{a}$ & $7.20 \pm 1.68 \mathrm{a}$ & 0.242 & 0.8671 & NS \\
\hline VR & $6.13 \pm 2.32$ & $6.34 \pm 1.97$ & $5.19 \pm 1.33$ & $6.47 \pm 1.32$ & - & - & - \\
\hline TPf & $3.88 \pm 1.75$ & $5.09 \pm 2.07$ & $4.18 \pm 1.95$ & $4.87 \pm 1.77$ & - & - & - \\
\hline VP & $4.27 \pm 1.56$ & $5.64 \pm 1.64$ & $4.60 \pm 1.88$ & $5.11 \pm 1.81$ & - & - & - \\
\hline VR & $2.95 \pm 1.90$ & $3.72 \pm 2.43$ & $3.17 \pm 1.81$ & $4.28 \pm 1.62$ & - & - & - \\
\hline $\mathrm{PO}_{4}{ }^{3-}$ & $2.15 \pm 1.83 \mathrm{a}$ & $3.77 \pm 2.78 \mathrm{~b}$ & $2.77 \pm 2.21 \mathrm{a}$ & $4.06 \pm 2.12 \mathrm{~b}$ & 6.264 & 0.0004 & *** \\
\hline VP & $2.15 \pm 1.81$ & $3.89 \pm 2.84$ & $2.71 \pm 2.30$ & $4.11 \pm 2.22$ & - & - & - \\
\hline VR & $2.18 \pm 1.99$ & $3.45 \pm 2.71$ & $2.93 \pm 2.03$ & $3.92 \pm 1.90$ & - & - & - \\
\hline
\end{tabular}

For each variable, means followed by the same letter are not significantly different at $5 \%$.

Non-significant (NS), significant (*), and very highly significant $(* * *)$ effects.

The N/P retention in helophyte tissues compared to the I-mesocosm vary sharply and reaches maxima of $6.39 \% / 7.86 \%$ in Pr for the aboveground/underground parts (Fig. 6), whereas by referring to the $\mathrm{N} / \mathrm{P}$ removal rate by the corresponding mesocosms, $\mathrm{T}$ recorded maxima of $14.8 \% / 33.6 \%$ for the aboveground (Fig. 7), suggesting a greater retention of $\mathrm{N}$ and $\mathrm{P}$ by the Pr-mesocosm compared to the T-one, contrary to the confirmation of Song et al. [18] for P.

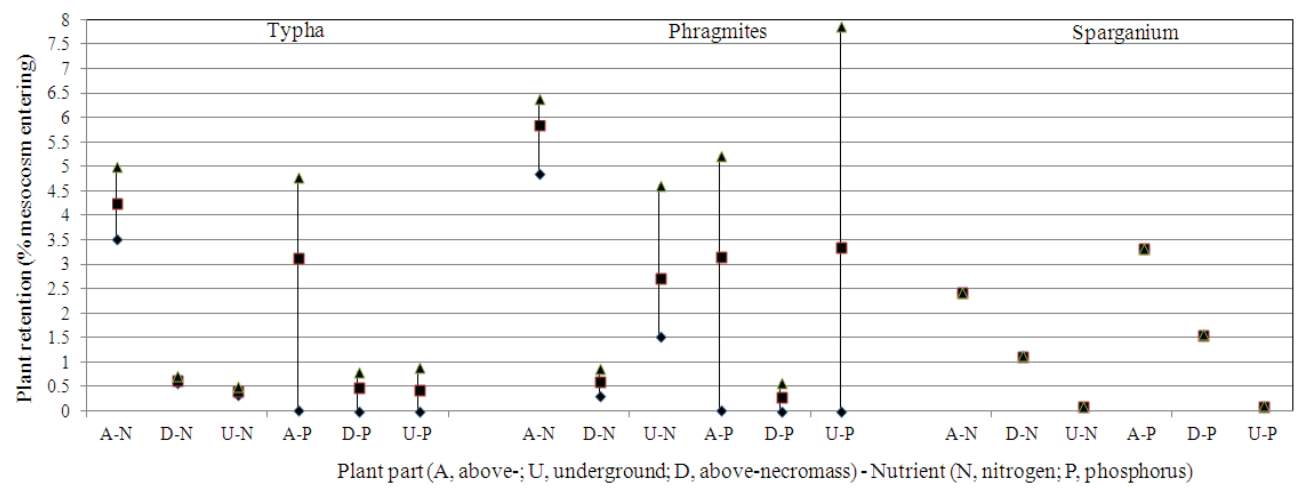

Fig. 6: Nitrogen and phosphorus retention in plant tissues in relation to the corresponding mesocosm inlet. 
Table 6: Nitrogen and phosphorus contents $\left(\mathrm{mg} . \mathrm{l}^{-1}\right)$ of inlet and outlets of L-, T-, and Pr-mesocosms (Secondary treatment; May 01 - Sep. 03).

\begin{tabular}{|c|c|c|c|c|c|c|c|}
\hline & \multirow{2}{*}{$\begin{array}{c}\text { Inlet } \\
\text { I2 }\end{array}$} & \multicolumn{3}{|c|}{ Outlets } & \multicolumn{3}{|c|}{ ANOVA significance $(p<0.05)$} \\
\hline & & L2 & $\mathrm{T} 2$ & $\operatorname{Pr} 2$ & F-ratio & F-prob. & Effet \\
\hline TN & $38.7 \pm 9.91 \mathrm{a}$ & $32.6 \pm 9.46 \mathrm{~b}$ & $31.4 \pm 9.17 \mathrm{~b}$ & $28.5 \pm 9.35 \mathrm{~b}$ & 11.18 & 0.0000 & $* * *$ \\
\hline VP & $41.0 \pm 10.2 \mathrm{a}$ & $34.7 \pm 10.3 \mathrm{~b}$ & $33.7 \pm 9.44 \mathrm{~b}$ & $29.8 \pm 10.1 \mathrm{~b}$ & 7.289 & 0.0001 & $* * *$ \\
\hline VR & $34.9 \pm 8.38 \mathrm{a}$ & $29.1 \pm 6.77 \mathrm{~b}$ & $27.7 \pm 7.52 \mathrm{~b}$ & $26.4 \pm 7.81 \mathrm{~b}$ & 5.053 & 0.0030 & ** \\
\hline TNf & $29.1 \pm 8.78 \mathrm{a}$ & $23.8 \pm 7.64 \mathrm{~b}$ & $23.0 \pm 8.25 \mathrm{~b}$ & $25.6 \pm 8.13 \mathrm{~b}$ & 6.209 & 0.0005 & $* * *$ \\
\hline VP & $31.3 \pm 9.29 \mathrm{a}$ & $25.0 \pm 8.17 \mathrm{~b}$ & $23.9 \pm 9.33 \mathrm{~b}$ & $27.6 \pm 8.02 \mathrm{~b}$ & 4.756 & 0.0035 & ** \\
\hline VR & $25.9 \pm 6.91 \mathrm{a}$ & $21.9 \pm 6.47 \mathrm{a}$ & $21.5 \pm 6.13 \mathrm{a}$ & $22.5 \pm 7.43 \mathrm{a}$ & 1.889 & 0.1377 & NS \\
\hline $\mathrm{NH}_{4}{ }^{+}$ & $23.8 \pm 7.57 \mathrm{a}$ & $18.2 \pm 6.73 \mathrm{~b}$ & $21.3 \pm 9.00 \mathrm{a}$ & $22.8 \pm 8.39 \mathrm{a}$ & 5.756 & 0.0008 & **** \\
\hline VP & $26.0 \pm 7.97 \mathrm{a}$ & $19.4 \pm 7.28 \mathrm{~b}$ & $23.2 \pm 10.4 \mathrm{a}$ & $25.6 \pm 8.55 \mathrm{a}$ & 4.881 & 0.0029 & ** \\
\hline VR & $19.8 \pm 4.77 \mathrm{a}$ & $16.0 \pm 5.10 \mathrm{a}$ & $17.8 \pm 4.23 \mathrm{a}$ & $17.8 \pm 5.35 \mathrm{a}$ & 2.156 & 0.0993 & NS \\
\hline $\mathrm{NO}_{2}$ & $0.023 \pm 0.045$ & $0.037 \pm 0.042$ & $0.023 \pm 0.044$ & $0.015 \pm 0.032$ & - & - & - \\
\hline VP & $0.023 \pm 0.042$ & $0.030 \pm 0.035$ & $0.022 \pm 0.042$ & $0.010 \pm 0.022$ & - & - & - \\
\hline VR & $0.022 \pm 0.050$ & $0.049 \pm 0.050$ & $0.026 \pm 0.050$ & $0.023 \pm 0.043$ & - & - & - \\
\hline $\mathrm{NO}_{3}^{-}$ & $2.80 \pm 1.82 \mathrm{a}$ & $2.62 \pm 2.16 \mathrm{a}$ & $3.91 \pm 2.03 \mathrm{~b}$ & $3.85 \pm 1.73 \mathrm{~b}$ & 7.301 & 0.0001 & *** \\
\hline VP & $3.28 \pm 2.00 \mathrm{a}$ & $3.31 \pm 2.31 \mathrm{a}$ & $4.43 \pm 2.29 \mathrm{~b}$ & $4.39 \pm 1.80 \mathrm{~b}$ & 3.530 & 0.0165 & * \\
\hline VR & $1.98 \pm 1.10 \mathrm{a}$ & $1.43 \pm 1.13 \mathrm{a}$ & $3.00 \pm 1.00 \mathrm{~b}$ & $2.91 \pm 1.10 \mathrm{~b}$ & 10.81 & 0.0000 & $* * *$ \\
\hline TP & $6.80 \pm 2.55 \mathrm{a}$ & $6.57 \pm 2.76 \mathrm{a}$ & $5.96 \pm 2.37 \mathrm{a}$ & $6.03 \pm 2.07 \mathrm{a}$ & 1.731 & 0.1612 & NS \\
\hline VP & $7.75 \pm 2.53 \mathrm{a}$ & $7.72 \pm 2.71 \mathrm{a}$ & $6.75 \pm 2.51 \mathrm{a}$ & $6.84 \pm 1.93 \mathrm{a}$ & 1.936 & 0.1261 & NS \\
\hline VR & $5.12 \pm 1.55 \mathrm{a}$ & $4.54 \pm 1.31 \mathrm{a}$ & $4.55 \pm 1.18 \mathrm{a}$ & $4.58 \pm 1.42 \mathrm{a}$ & 0.910 & 0.4398 & NS \\
\hline TPf & $4.20 \pm 1.87 \mathrm{a}$ & $3.84 \pm 2.09 \mathrm{a}$ & $4.59 \pm 2.23 \mathrm{a}$ & $4.47 \pm 1.83 \mathrm{a}$ & 1.653 & 0.1779 & NS \\
\hline VP & $4.95 \pm 1.69 \mathrm{a}$ & $4.67 \pm 2.09 \mathrm{a}$ & $5.22 \pm 2.48 \mathrm{a}$ & $5.09 \pm 1.90 \mathrm{a}$ & 0.510 & 0.6756 & NS \\
\hline VR & $2.88 \pm 1.39$ & $2.36 \pm 1.01$ & $3.46 \pm 1.02$ & $3.36 \pm 1.04$ & - & - & - \\
\hline $\mathrm{PO}_{4}{ }^{3-}$ & $2.94 \pm 2.01 \mathrm{a}$ & $2.71 \pm 2.16 \mathrm{a}$ & $4.02 \pm 2.15 \mathrm{~b}$ & $3.95 \pm 1.84 \mathrm{~b}$ & 6.751 & 0.0002 & **** \\
\hline VP & $3.47 \pm 2.22 \mathrm{a}$ & $3.40 \pm 2.31 \mathrm{a}$ & $4.59 \pm 2.42 \mathrm{~b}$ & $4.52 \pm 1.94 \mathrm{~b}$ & 3.300 & 0.0221 & * \\
\hline VR & $2.00 \pm 1.08 \mathrm{a}$ & $1.48 \pm 1.11 \mathrm{a}$ & $3.03 \pm 0.99 \mathrm{~b}$ & $2.94 \pm 1.08 \mathrm{~b}$ & 10.86 & 0.0000 & $* * *$ \\
\hline
\end{tabular}

For each variable, means followed by the same letter are not significantly different at $5 \%$.

Non-significant (NS), significant $(*)$, highly significant $(* *)$, and very highly significant $(* * *)$ effects.

For the whole plant, Pr assimilates in its tissues $10.9 \% \mathrm{~N}$ and $13.1 \% \mathrm{P}$ compared to the I-mesocosm load. These values of N/P accumulated in aboveground plant tissues are far below than those obtained by de los Reyes et al. [26] in $\mathrm{T}(29.6 \% \mathrm{~N})$ and Zheng et al. [6] in $\operatorname{Pr}(16.2-17.04 \% \mathrm{~N})$. Besides, $\mathrm{T}$ is more effective in the $\mathrm{N}$ retention in its aerial tissues in secondary treatment and $\mathrm{P}$ in the whole plant in secondary treatment. Pr offers more efficiency of $\mathrm{N}$ absorption in its aerial part in secondary treatment and $\mathrm{N}$ and $\mathrm{P}$ in its underground part in tertiary treatment.

The underground part of Pr retains at most $5.23 \% \mathrm{~N}$ and $15.1 \% \mathrm{P}$ of the general elimination rate of the corresponding mesocosm, and can be released progressively because of tissue death and decomposition during the forthcoming seasons. The $\mathrm{S}$ necromass in water is valued at up to $2.94 \% \mathrm{~N}$ and $7.96 \% \mathrm{P}$ the general retention of the corresponding mesocosm, and will recover more rapidly in the treatment system given the relatively rapid decomposition of its collapsed shoots [31].

\section{CONCLUSION}

This work focused on the monitoring of $T$. angustifolia, $P$. australis and $S$. erectum grown in constructed surface flow wetlands for urban wastewater treatment in a Mediterranean climate, based on growth and functional criteria, and allowed an interspecific comparison under the same growing conditions on the one hand, and within each species by reference to natural-polluted environments on the other hand. 
Table 7: Nitrogen and phosphorus contents $\left(\mathrm{mg} . \mathrm{l}^{-1}\right)$ of inlet and outlets of L-, T-, and Pr-mesocosms (Tertiary treatment; Jan. 99 - Sep. 00).

\begin{tabular}{|c|c|c|c|c|c|c|c|}
\hline & \multirow{2}{*}{$\begin{array}{c}\text { Inlet } \\
\text { I3 }\end{array}$} & \multicolumn{3}{|c|}{ Outlets } & \multicolumn{3}{|c|}{ NOVA significance $(p<0.05)$} \\
\hline & & L3 & T3 & Pr3 & F-ratio & F-prob. & Effet \\
\hline TN & $22.8 \pm 8.45 \mathrm{a}$ & $12.4 \pm 6.10 \mathrm{~b}$ & $12.9 \pm 6.42 \mathrm{~b}$ & $7.45 \pm 5.96 \mathrm{c}$ & 35.80 & 0.0000 & $* * *$ \\
\hline VP & $24.4 \pm 9.38 \mathrm{a}$ & $14.2 \pm 6.65 \mathrm{~b}$ & $15.4 \pm 6.34 \mathrm{~b}$ & $7.68 \pm 4.92 \mathrm{c}$ & 24.23 & 0.0000 & $* * *$ \\
\hline VR & $20.1 \pm 5.97$ & $9.53 \pm 3.66$ & $8.73 \pm 3.97$ & $7.07 \pm 7.56$ & - & - & - \\
\hline TNf & $17.7 \pm 5.29 \mathrm{a}$ & $7.26 \pm 3.92 \mathrm{~b}$ & $10.4 \pm 6.02 \mathrm{c}$ & $5.84 \pm 4.41 \mathrm{~b}$ & 43.00 & 0.0000 & $* * *$ \\
\hline VP & $18.4 \pm 5.39 \mathrm{a}$ & $6.88 \pm 3.57 \mathrm{~b}$ & $12.0 \pm 6.23 \mathrm{c}$ & $5.56 \pm 3.68 b$ & 36.29 & 0.0000 & $* * *$ \\
\hline VR & $16.3 \pm 5.01$ & $8.00 \pm 4.56$ & $7.38 \pm 4.37$ & $6.38 \pm 5.69$ & - & - & - \\
\hline $\mathrm{NH}_{4}^{+}$ & $14.0 \pm 4.81 \mathrm{a}$ & $3.17 \pm 2.23 \mathrm{~b}$ & $7.30 \pm 4.51 \mathrm{c}$ & $2.74 \pm 2.54 \mathrm{~b}$ & 82.06 & .00000 & $* * *$ \\
\hline VP & $15.2 \pm 4.27 \mathrm{a}$ & $3.42 \pm 2.57 \mathrm{~b}$ & $8.53 \pm 4.81 \mathrm{c}$ & $2.99 \pm 2.63 \mathrm{~b}$ & 68.87 & 0.0000 & $* * *$ \\
\hline VR & $11.18 \pm 4.92$ & $2.61 \pm 1.05$ & $4.73 \pm 2.45$ & $2.38 \pm 2.35$ & - & - & - \\
\hline $\mathrm{NO}_{2}^{-}$ & $0.065 \pm 0.053$ & $0.121 \pm 0.090$ & $0.021 \pm 0.034$ & $0.024 \pm 0.028$ & - & - & - \\
\hline VP & $0.073 \pm 0.064$ & $0.116 \pm 0.099$ & $0.020 \pm 0.040$ & $0.018 \pm 0.025$ & - & - & - \\
\hline VR & $0.051 \pm 0.018$ & $0.132 \pm 0.073$ & $0.024 \pm 0.022$ & $0.035 \pm 0.030$ & - & - & - \\
\hline $\mathrm{NO}_{3}^{-}$ & $0.779 \pm 0.598 \mathrm{a}$ & $0.743 \pm 0.951 \mathrm{a}$ & $0.448 \pm 0.731 \mathrm{a}$ & $0.245 \pm 0.344 \mathrm{a}$ & 2.694 & 0.0519 & NS \\
\hline VP & $0.679 \pm 0.653$ & $0.428 \pm 0.773$ & $0.122 \pm 0.047$ & $0.132 \pm 0.114$ & - & - & - \\
\hline VR & $0.929 \pm 0.507$ & $1.214 \pm 1.044$ & $0.936 \pm 0.996$ & $0.413 \pm 0.497$ & - & - & - \\
\hline TP & $4.94 \pm 1.52$ & $4.24 \pm 1.81$ & $4.46 \pm 1.56$ & $3.82 \pm 1.81$ & - & - & - \\
\hline VP & $5.49 \pm 1.48$ & $4.75 \pm 2.08$ & $5.13 \pm 1.49$ & $4.41 \pm 1.99$ & - & - & - \\
\hline VR & $4.14 \pm 1.17$ & $3.48 \pm 0.81$ & $3.50 \pm 1.04$ & $3.01 \pm 1.06$ & - & - & - \\
\hline TPf & $3.05 \pm 1.42$ & $2.31 \pm 1.09$ & $3.15 \pm 1.30$ & $2.66 \pm 1.71$ & - & - & - \\
\hline VP & $3.40 \pm 1.30$ & $2.38 \pm 1.09$ & $3.56 \pm 1.24$ & $3.11 \pm 1.85$ & - & - & - \\
\hline VR & $2.46 \pm 1.47$ & $2.18 \pm 1.13$ & $2.47 \pm 1.15$ & $1.90 \pm 1.10$ & - & - & - \\
\hline $\mathrm{PO}_{4}{ }^{3-}$ & $2.32 \pm 1.39 \mathrm{a}$ & $2.17 \pm 0.93 \mathrm{a}$ & $3.07 \pm 1.30 \mathrm{~b}$ & $2.26 \pm 0.84 \mathrm{a}$ & 5.360 & 0.0015 & $* *$ \\
\hline VP & $2.41 \pm 1.33$ & $2.29 \pm 0.97$ & $3.43 \pm 1.31$ & $2.49 \pm 0.78$ & - & - & - \\
\hline VR & $2.14 \pm 1.56$ & $1.91 \pm 0.80$ & $2.29 \pm 0.92$ & $1.77 \pm 0.79$ & - & - & - \\
\hline
\end{tabular}

For each variable, means followed by the same letter are not significantly different at $5 \%$. Non-significant (NS), highly significant $(* *)$, and very highly significant $(* * *)$ effects.

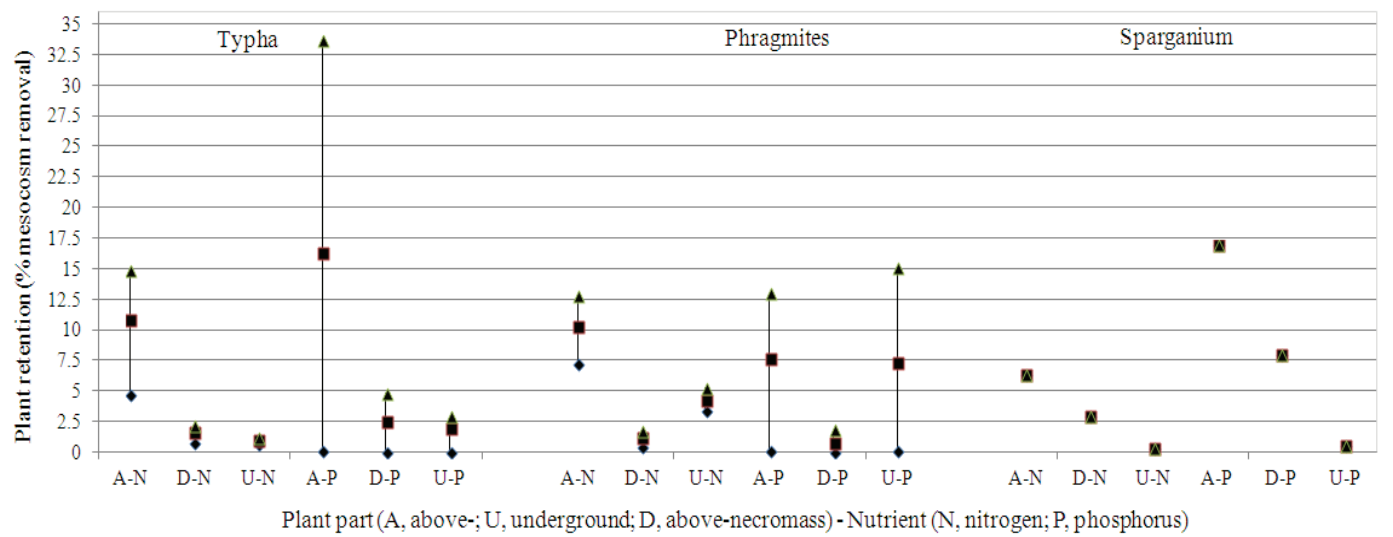

Fig. 7: Nitrogen and phosphorus retention in plant tissues in relation to the corresponding mesocosm efficiency.

In Mediterranean climate the Phragmites mesocosm is more effective in plankton reduction especially in tertiary treatment, compared to a lesser role of the Typha and Sparganium ones. By helophyte harvesting at the end of each vegetative period, there is relative stability of biomass production by Phragmites in tertiary treatment, resilience for Phragmites and Sparganium in secondary treatment, while Typha increases biomass 
production the first two years and falls steeply the third year. Moreover, the aerial biomass of the three helophytes seems to be slightly disadvantaged in tertiary treatment.

Given the development magnitude of its underground biomass, Phragmites is by far the most cumulative of nitrogen and phosphorus in this part, in addition to the indirect benefit of substrate oxygenation, an interesting aspect for wastewater treatment. Phragmites also accumulates more nitrogen in its aboveground part in secondary treatment, and the nitrogen and phosphorus in its underground part in tertiary treatment. In secondary treatment Typha shows a specific interest in the assimilation of nitrogen in aerial tissues, and phosphorus in the whole plant.

\section{ACKNOWLEDGEMENT}

This study was carried out as part of the MHEA ${ }^{\circledR}$ project, achieved in M'Diq (NW of Morocco) via the Agence de la Francophonie (Walloon Region-Morocco).

\section{REFERENCES}

[1] Radoux M. (1989) Epuration des eaux usées par hydrosère reconstituée. Trib. CEBEDEAU, 42(8):62-68.

[2] Greenway M. (2003) Suitability of macrophytes for nutrient removal from surface flow constructed wetlands receiving secondary treated sewage effluent in Queensland, Australia. Water Sci. Technol., 48(2):121-128. https://doi.org/10.2166/wst.2003.0101

[3] Vymazal J. (2013) Emergent plants used in free water surface constructed wetlands: A review. Ecol. Eng., 61(Part B):582-592. https://doi.org/10.1016/j.ecoleng.2013.06.023

[4] Brix H. (1997) Do macrophytes play a role in constructed treatment wetlands? Water Sci. Technol., 35(5):11-17. https://doi.org/10.2166/wst.1997.0154

[5] Greenway M, Woolley A. (1999) Constructed wetlands in Queensland: Performance efficiency and nutrient bioaccumulation. Ecol. Eng., 12(1-2):39-55. https://doi.org/10.1016/S09258574(98)00053-6

[6] Zheng Y, Wang XC, Ge Y, Dzakpasu M, Zhao Y, Xiong J. (2015) Effects of annual harvesting on plants growth and nutrients removal in surface-flow constructed wetlands in northwestern China. Ecol. Eng., 83:268-275. https://doi.org/10.1016/j.ecoleng.2015.06.035

[7] Korkusuz EA. (2005) Manual of practice on constructed wetlands for wastewater treatment and reuse in mediterranean countries; AVKR 5 - Technical Report Med-Reunet II (INCO-CT2003-502453): Agbar Foundation Barcelona.

[8] Ezzahri J, Ennabili A, Ater M, Radoux M. (2001) Epuration des eaux usées urbaines : Expérimentation sous climat méditerranéen (M’Diq, Nord-ouest du Maroc). Ann. Chim. Sci. Mat., 26:S297-311.

[9] Ezzahri J, Ennabili A, Radoux M (2010) Artificial ecosystems for wastewaters treatment under Mediterranean conditions (Morocco). Biol. Divers. Conserv. 3/2:145-150. Retrieved from http://www.biodicon.com/YayinlananMakaleler/7.15.pdf

[10] Radoux M, Cadelli D, Nemcova M, Ennabili A, Ezzahri J. (2003) Optimisation of extensive wastewater treatment systems under Mediterranean conditions (Morocco): compared purification efficiency of artificial ecosystems. In Wetlands: nutrients, metals and mass Cycling; Vymazal, J., Ed. Backhuys Publishers: Leiden, NL, pp. 143-168.

[11] Ennabili A. (1999) Végétation hygrophile du Maroc méditerranéen: écologie, socio-économie et rôle potentiel dans l'épuration des eaux usées. PhD thesis. University of Liege, Department of Environmental Sciences and Management.

[12] Ezzahri J. (2005) Optimisation de l'épuration naturelle des eaux usées domestiques urbaines dans le contexte climatique et socio-économique du Nord du Maroc (M'Diq). PhD thesis. University of Liege, Department of Environmental Sciences and Management. 
[13] Standard Methods. (1995) Standard Methods for the Examination of Water and Wastewater, $19^{\text {th }}$ edn, American Public Health Association/American Water Works Association/Water Environment Federation: Washington D.C.

[14] Ennabili A, Ater M, Radoux M. (1998) Biomass production and NPK-retention in macrophytes from wetlands of the Tingitan Peninsula. Aquat. Bot. 62(1):45-56. https://doi.org/10.1016/S0304-3770(98)00075-8

[15] Ennabili A. (2008) Régénération in vivo de macrophytes originaires des zones humides du Maroc méditerranéen. Rev. Assoc. Forum Nord Maroc, 2-3:116-124. Retrieved from http://revue-afnm.org/b2e/numero-2-3/regeneration-in-vivo-de-macrophytes

[16] Abou-Elela SI, Golinielli G, Abou-Taleb EM, Hellal MS. (2013) Municipal wastewater treatment in horizontal and vertical flows constructed wetlands. Ecol. Eng., 61(Part A):460468. https://doi.org/10.1016/j.ecoleng.2013.10.010

[17] Zhang J, Sun H, Wang W, Hu Z, Yin X, Ngo HH, Guo W, Fan J. (2017) Enhancement of surface flow constructed wetlands performance at low temperature through seasonal plant collocation. Bioresour. Technol., 224:222-228. https://doi.org/10.1016/j.biortech.2016.11.006

[18] Song U, Waldman B, Park JS, Lee K, Park SJ, Lee EJ. (2018) Improving the remediation capacity of a landfill leachate channel by selecting suitable macrophytes. J. Hydro-Environ. Res., 20:31-37. https://doi.org/10.1016/j.jher.2018.04.005

[19] Ennabili A, Gharnit N. (2003) Effets d'aménagements du littoral tétouanais (Nord-ouest du Maroc) sur la végétation hygrophile (Spermatophyta). Acta Bot. Barc., 48:199-216.

[20] Asaeda T, Rajapakse L, Kanoh M. (2010) Fine sediment retention as affected by annual shoot collapse: Sparganium erectum as an ecosystem engineer in a lowland stream. River Res. Appl., 26(9):1153-169. https://doi.org/10.1002/rra.1322

[21] Liffen T, Gurnell AM, O'Hare MT. (2013) Profiling the below ground biomass of an emergent macrophyte using an adapted ingrowth core method. Aquat. Bot., 110:97-102. https://doi.org/10.1016/j.aquabot.2013.05.008

[22] Asaeda T, Rajapakse L, Manatunge J, Sahara N. (2006) The effect of summer harvesting of Phragmites australis on growth characteristics and rhizome resource storage. Hydrobiologia, 553:327-335. https://doi.org/10.1007/s10750-005-1157-6

[23] Maddison M, Soosaar K, Mauring T, Mander Ü. (2009) The biomass and nutrient and heavy metal content of cattails and reeds in wastewater treatment wetlands for the production of construction material in Estonia. Desalination, 246(1-3):120-128. https://doi.org/10.1016/j.desal.2008.02.040

[24] Boyd MC, Brown MT, Brandt-Williams S. (2015) Addressing pollutant load reduction goals for impaired waterbodies through biomass harvest of Gulf Coast type Phragmites australis (common reed). Wetlands Ecol. Manage., 23:519-533. https://doi.org/10.1007/s11273-0159406-6

[25] Tanaka TST, Irbis C, Kumagai H, Inamura T. (2016) Timing of harvest of Phragmites australis (CAV.) Trin. ex Steudel affects subsequent canopy structure and nutritive value of roughage in subtropical highland. J. Environ. Manag., 166:420-428. https://doi.org/10.1016/j.jenvman.2015.10.055

[26] de los Reyes CP, Villamar CA, Neubauer ME, Pozo G, Vidal G. (2013) Behavior of Typha angustifolia L. in a free water surface constructed wetlands for the treatment of swine Wastewater. J. Environ. Sci. Health, Part A: Toxic/Hazard. Subst. Environ. Eng., 48(10):1216-224. https://doi.org/10.1080/10934529.2013.776852

[27] Maucieri C, Salvato M, Tamiazzo J, Borin M. (2014) Biomass production and soil organic carbon accumulation in a free water surface constructed wetland treating agricultural wastewater in North Eastern Italy. Ecol. Eng., 70:422-428. https://doi.org/10.1016/j.ecoleng.2014.06.020

[28] Borin M, Tocchetto D. (2007) Five year water and nitrogen balance for a constructed surface flow wetland treating agricultural drainage waters. Sci. Total Environ., 380(1-3):38-47. https://doi.org/10.1016/j.scitotenv.2006.12.039 
[29] Li EH, Li W, Wang XL, Xue HP, Xiao F. (2010) Experiment of emergent macrophytes growing in contaminated sludge: Implication for sediment purification and lake restoration. Ecol. Eng., 36(4):427-434. https://doi.org/10.1016/j.ecoleng.2009.11.009

[30] Das SC, Tanaka N (2007) Estimating nitrogen budgets of Typha angustifolia by considering the regrowth shoot productivity and nitrogen content after harvesting aerial organs in different growing seasons. Landsc. Ecol. Eng., 3:99-108. https://doi.org/10.1007/s11355007-0024-1

[31] Asaeda T, Rashid MH. (2015) Nutrient retention associated with phenological features in Sparganium erectum stands in a lowland stream. River Res. Appl., 31(2):207-215. https://doi.org/10.1002/rra.2733

[32] Chicalote-Castillo D, Ramírez-García P, Macías-Rubalcava ML. (2017) Allelopathic effects among selected species of phytoplankton and macrophytes. J. Environ. Biol., 38(Special issue):1221-227. http://dx.doi.org/10.22438/jeb/38/6(SI)/07

[33] Zhang TT, Hu W, Zhang D. (2012) Allelopathic effect of Typha angustifolia L. on phytoplankton. Adv. Mater. Res.-Switz., 383-390:3724-728. http://dx.doi.org/10.4028/www.scientific.net/AMR.383-390.3724

[34] Gross EM. (2003) Allelopathy of aquatic autotrophs. Crit. Rev. Plant Sci., 22(3-4):313-339. https://doi.org/10.1080/713610859 